5.

\title{
Beobachtungen über das Vorkommen der Bilharzia haematobia.
}

Briefliche Mittheilung an den Herausgeber.

\section{Von John Wortabeh zu Beirut.}

(Hr. Wortabeb hatte die Güte, mir mit nachstehendem Briefe einige Präparate von Blut, antermischt mit Urin, zu schicken. Obwohl darin starke Zersetzung unter Bakterienbildung eingetreten war, so fand ich doch noch zahlreiche Eier der Bilharzia [Distomum haematobium v. Sieb]. Einigemal sah ich darin auch noch Embryonen.

Virchow.)

I have had lately two cases under my observation - one of which is still under my care in St. John's Hospital - which I have been patiently studying and hope soon to report to some med. Journal in England. The following are some of the main points connected with this disease:

1. The chief symptoms are a small quantity of blood - from one to a few drops - voided after micturition with a little strangury - the constitution a little weakened, but otherwise not much aflected.

2. The ova are always found in the clots. Their form is more regular than is generally given in books. The embryo may be distinctly seen within the shell - sometimes moving.

3. A free embryo may be occasionaliy seen with its eilia in action. From fresh specimens I have often succeeded in gently crushing the egg, by pressing the glasses, and thus liberating the embryo in a living state.

4. I once opened a vein in the arm - but found no ova in the blood. 